\title{
RETRANSLATION IN CONTEXT
}

\author{
Piet Van Poucke 1 \\ ${ }^{1}$ Ghent University, Ghent, Bélgica \\ Guillermo Sanz Gallego 2 \\ ${ }^{2}$ Ghent University, Ghent/Vrije Universiteit, Brussel, Bélgica
}

One could have thought that Isabelle Collombat was rather provocative and courageous when in 2004, at the turn of the new century, she already proclaimed the $21^{\text {st }}$ century as the "Age of Retranslation". Her judgement was based on the finding that a "wave" of (literary) retranslations was occurring at the beginning of the new century, and that that wave was motivated by a number of "translatorly concerns" (1) among which could be discerned: the ageing of previously translated texts, ideological considerations in connection with changing cultural norms, and the ever continuing search for the perfect translation, which Berman (2-3) called the "great translation" ("grande traduction") in his seminal article on retranslation in 1990. The three aforementioned motives for retranslation share at least one overarching consideration - the translator's desire to leave a trace in cultural history by creating a personal, contemporary, fully acceptable and at the same time artistically innovative interpretation of the big works of 'World Literature'. With the number of canonized literary works growing, the number of retranslations should, indeed, increase as well.

However, the activity of retranslating texts is obviously not a new phenomenon. Retranslations have always constituted a considerable share of the global translation market ever since the Middle Ages. Not only canonical literary works, but also 
religious, political, historical and philosophical texts have always been translated and retranslated into several languages, and this process has only increased with time. A decade and a half after Collombat's daring claim, it is difficult to determine whether the $21^{\text {st }}$ century will actually produce considerably more retranslations than the ages that have passed, but we do know that retranslation, indeed, has become a very common practice and, recently, a serious topic of inquiry in the context of Translation Studies, as well as within Literature Studies.

When Palimpsestes devoted its entire $4^{\text {th }}$ volume $(1990)$ to the theme of "retranslation" ("Retraduire"), it was up to the editors of the volume, Antoine Berman and Paul Bensimon, to outline the possibly problematic nature of the concept, often overlooked as an object for thorough scholarly investigation. At that point Berman suggested a few lines of analysis that have become major sources of inspiration in the course of time: the so-called 'Retranslation Hypothesis', the concept of "great translation", and the related issue of ageing of translations, to name only a few well investigated lines.

In the wake of this initial impetus there followed a long 'comet's tail' of studies on retranslation, mainly focused on literary retranslation, that first took the form of separate theoretical articles and case studies, and later on merged into a number of special volumes on retranslation - Palimpsestes 4 (1990), Cadernos de Tradução (2003), Palimpsestes 15 (2004), Target (2015) and now this latest issue of Cadernos de Tradução. "Retranslation" has by now also been included as an entry in the Routledge Encyclopedia of Translation Studies (Tahir Gürçağlar 2009) and the Handbook of Translation Studies (Koskinen \& Paloposki 2010). Finally, retranslation is also the central topic of a growing number of monographs and collections of articles, as for instance Banoun \& Weber Henking (2007), Kahn \& Seth (2010), Monti \& Schnyder (2011), O’Driscoll (2011), Pokorn (2012), Béghain (2013), Courtois (2014), Deane-Cox (2014), Douglas \& Cabaret (2014), Cadera \& Walsh (2017) and Berk Albachten \& Tahir Gürcaglar (2018). 
A detailed overview of research lines developed so far within the study of retranslations is given by Alvstad \& Rosa in their introduction to the special issue of Target on Voice in Retranslation in 2015. Themes related to retranslation, but still insufficiently explored at this moment include the history of literary retranslation and its relationship to the history of literary translation, the specific role of the different agents involved in the process (translators, publishers, editors, censors, reviewers, and readers) and the importance of retranslation in the canonization process of literary works that belong to the category of 'World Literature'. A number of different motives for retranslation have been defined, but some of them (e.g. ageing, adaptation to changing cultural and ethical norms, the role of ideology) still lack thorough empirical underpinning. In the same vein, economic considerations for retranslation must also be examined (e.g. the cost-effectiveness of publishers' investments in retranslations instead of revising or simply reediting an existing translation), together with the reviewers' and readers' appreciation of the (expected) improvement.

Specific research into the different aspects of retranslation, from the decision to retranslate to the reception of a retranslated work, can still shed additional light on a broad range of related questions. In a number of cases translators decide to self-retranslate a text: How is this reflected in the paratext and to what extent is the translator willing to 'correct' his/her own translation? Is 'indirect translation' a form of retranslation? And what is the impact of an intermediate translation on the final product? Are 'cold retranslations' (made well after the publication of the source text) fundamentally different from 'hot translations' (made immediately after its publication)? Indeed, a number of macro-level issues invite further reflection as well: Do central and peripheral literary systems adopt different policies towards retranslation? Are retranslations fundamentally different from earlier translations, or would it be more accurate to regard them as 'revisions', and how is this related to questions of authorship and plagiarism? 
In the majority of the cases up to now the analysis of retranslation(s) concerns literary translation. However, for a few years now the attention of scholars has shifted towards retranslation in a much broader range of domains and fields and the initial focus on texts and translational shifts gave way to a more contextual approach of all kinds of genres and narratives. This change in approach is reflected in the papers from the series of "Retranslation in Context" conferences, initiated in Istanbul in 2013, and successfully continued in 2015 (Istanbul), 2017 (Ghent), and 2019 (Madrid). By abandoning the traditional method of comparing different translations of one and the same text on microtextual level and including other considerations on macro-textual and contextual levels in the analysis, a range of new 'highways' of investigation are discovered, proof of which can be found in the papers in this volume.

The selected papers in this special volume discuss the concept of retranslation in its broadest meaning and focus specifically on the contextual circumstances in which the retranslations in question came into being (or not) as a result of the specific background of that particular period. All these papers constitute a representative echo of the changing flows in 'Retranslation Studies' - if we are allowed to use this terminology without claiming to divide Translation Studies up into a scattered field of subdomains and small niches - as they overarch a broad spectrum of (often mutually complementary) research methodologies and angle to look at retranslation in a number of alternative contexts. The viability of the concept of retranslation as an object of investigation is perfectly shown by the fact that 'Retranslation Theory' - a term coined by Siobhan Brownlie in 2006 - is constantly expanding, and new methodologies are suggested on a regular basis. The scope of the articles in this volume includes calls for more macro level research, an analysis of the role of 'non-retranslation' and a new interpretation of the concept of retranslation, but also a range of case studies on retranslations of philosophical texts, literary prose, poetry and lyrics. Moreover, the strictly contextual approach to 
retranslation is witnessed in two articles of the volume, which focus on the process of retranslation (through eye-tracking) and the economics of retranslation (the interaction between marketing techniques and reception).

The curious concept of 'non-retranslation' is the direct and indirect object of investigation in the two first papers of the volume. The opening article by Kaisa Koskinen and Outi Paloposki departs from the research data on retranslation in the Finnish literary system, collected in the course of time by the authors. They plead for a more comprehensive, macro-level approach to the analysis of retranslation, as retranslation has been a topic for analysis in many articles so far, but often the analysis does not go beyond the scope of a single case study, based on a limited set of data and covering only one cultural system, period or genre. Koskinen and Paloposki call upon scholars to break through the walls of the individual case studies and look for the "bigger picture". As individual case studies "do not easily add up" because of dissimilarities in methodology, scholars should start comparing empirical evidence from larger data sets. Accordingly, instead of coordinating material from different historical periods, they should also take into consideration different cultures and literary contexts, in order to ask - and answer - new research questions that open the path for macro-level empirical evidence and a better understanding of the concept as a whole. Their quest for new approaches to retranslation leads them in particular to the discovery that apart from retranslation, 'non-retranslation' is an equally significant aspect of retranslation, that has attracted relatively little scholarly interest so far.

This particular issue - the importance of 'non-retranslation' for translation analysis, and translation history in particular -, is picked up by Charlotte Bollaert in her paper on translations of Jean-Paul Sartre in Russia. She investigates the controversies of selection, 
translation, retranslation, non-translation, non-retranslation and reprinting of Sartre's theatre plays, both in the Soviet Union and in contemporary Russia. The contextual analysis of the translation policy towards Sartre reveals the presence of a contradictory and at the same time hardly surprising double normativity. On the one hand, the reprinting - which is the reverse of the non-(re) translation medal - of Sartre's work in Russia today is driven by economic considerations, as reprinting is obviously cheaper than the assignment of a retranslation. At the same time one gets the impression that the ideological (communist) considerations that made Sartre persona non grata for a certain period in the Soviet period continue to be active, hindering the further dissemination of Sartre in Russian, even three decades after the ideological landslides that officially abolished the censorship of literary works in Russia.

Admittedly, the concept of retranslation is closely related to another concept - that of canonization. The more historical a text becomes, the more motives for retranslation are activated, going from refreshing the ageing language of an older translation to radically censoring and adapting an older translation to bring it in accordance with changing cultural or political norms. Against this background Sonja Lavaert investigates the publication history of the $17^{\text {th }}$ century clandestine treatise Traité des trois imposteurs, that in itself could be considered as a retranslation effort. The text consists of a compilation of paraphrases and quotations of several heterodox texts, combined together into one whole. The paper discusses in particular how apparently different translation strategies and decisions may lead to significant shifts in meaning and interpretation. A work on "Renaissance panteism" suddenly seems to discuss "atheism and materialism" without apparent traces of mutilation or censorship. Lavaert demonstrates, by comparing two excerpts of the treatise in detail, how different interpretations of the work in French and Italian relate to the respective contextual factors of their times, as the first 'translation' dates back to 1719 , whereas the 'retranslation' was made in 1768. 
Guy Rooryck and Lieve Jooken compare (re)translation strategies and norms from two very distant historical periods as they confront a 'hot', 18 $8^{\text {th }}$ century English version of Voltaire's Lettres philosophiques - Letters concerning the English Nation from 1733, attributed to John Lockman - with three 'cold' retranslations from 1961, 1980 and 2007. On the basis of a microanalysis of translations of two 'letters' the authors demonstrate how the more incisive approach adopted by the $18^{\text {th }}$ century translator leads to a much clearer and more direct narrative than the modern versions, which - according to modern translation norms reproduce Voltaire's evasive voice in a more faithful way, but at the same time fail to "transmit the marks of subversion" that Voltaire clearly intended to pass on, but had to hide for censorial reasons. Because of the loss of "historical simultaneity" between the source text and the readers of the most recent translations, the contextual aspect is obviously lost in the modern translations. The contradictory conclusion of the analysis suggests that modern, (allegedly) 'faithful' translation strategies may sometimes blur the message of an $18^{\text {th }}$ century narrative.

(Re)translation of $19^{\text {th }}$ century Russian literature is the topic of Pieter Boulogne's paper on Dutch (re)translations of Dostoevsky. $\mathrm{He}$ "tries to explain the phenomena of retranslation in general" by comparing not only textual, but also contextual features of retranslation. Boulogne confronts two central concepts of Translation Studies - the Retranslation Hypothesis on the one hand, claiming that successive retranslations tend to be more faithful to the source text than the first translation, and the concept of 'translation norms' on the other hand. The author concludes that the latter appear to be "a better tool" to "explain the phenomenon of the Dostoevsky retranslations into Dutch". However, at the same time the concept of norms is to be seen as no more than a limited reflection of certain prescriptive rules, rather than a universal phenomenon. In the specific case of Dutch translations of Dostoevsky the individuality of the translators who continue to follow their own idiosyncratic 
rules and consistently "go against the norms" is no less important than the prevailing 'rules' of literary (re)translation.

The next two papers in the volume discuss the retranslation of $20^{\text {th }}$ and $21^{\text {st }}$ century poetry into French. Francis Mus investigates how various translations of Leonard Cohen's poetry collection Book of Longing were published, once in Québec and twice in France, between 2001 and 2008. The author first compares the translations at a textual level in order to find out how translators interpreted Cohen's poetry, and to determine whether the different versions of the English source text can be considered as retranslations at all. Subsequently, he investigates whether the differences in the translations can be explained by contextual factors of space and genre. In particular, Mus analyses the two main "power mechanisms" that could have "influenced the production of these translations": on the one hand, the three translations belong to two different cultural systems - one that is considered as 'central' (Paris), and one 'peripheral' (Québec); and on the other hand the translations serve divergent purposes, as we are dealing with the contrast between highbrow- (belles lettres) and lowbrow- (lyrics) literature.

Cristina Vignali discusses different translations of a literary work "whose nature lies mid-way between the illustrated poems and comic strips genres" and, hence, poses particular challenges for the translators. Because of the specific interaction between text and image, the translators have to make sure the link between the textual and the visual is not cut through. At the same time translators have to interpret the multitude of contextual features that accompany the story. Dino Buzzati wrote his Poema a fumetti in a period of "contestation, disobedience", and "the start of sexual liberation, and secularization" of society. In her analysis Vignali confronts the 'hot' French translation from 1970 with the 'cold' retranslation from 2007 and concludes that the most recent interpretation differs significantly from the source text. Apparently, the retranslator felt compelled to interpret the original publication for the new generation of readers, by elucidating the connotative information included in the source text, which was part of the 
common knowledge for the reader of the source text (and the first translation) at the time, but evokes significantly different reactions half a century later.

The final section of this volume is dedicated to new and alternative approaches to retranslation. The papers in this section go beyond the more 'classical' textual and paratextual analysis of literary texts, but suggest new lines of investigation. Gleiton Malta, Cristiane Silva Fontes and Igor Lourenço da Silva focus not on the product of retranslating, but on the process itself, and more specifically on the cognitive processes that are at stake when translators are asked to retranslate a text. The authors depart from an experimental research setting and report on the decisions made by retranslators who have at their immediate disposal not only the source text, but also two other translations. Their pioneering research builds on eye-tracking tools to investigate the visual attention of the retranslators. The analysis reveals the incidental attention devoted to previous translations, as "the most frequent flow of visual attention" during the experiment goes from target text to source text and vice-versa, and only occasionally from target text to the previous translations. Despite the limited character of the experiment, the article opens up several possibilities for further investigation, in particular to be "applied in the classroom as a way to raise students' awareness of what retranslation is".

Mary Wardle goes beyond the lines of (more traditional) processand product-oriented research, in order to explore the sometimes contradictory tools of marketing and reception of retranslations in a digital environment. The author focuses on the competition between bigger international and smaller independent publishing houses and their different approaches towards retranslations. As independent publishers are expected to be more risk averse and therefore to be "keen to commission retranslations as safe bets", this is expected to have an influence on sales and reception as well. As books are sold more and more often online, different sellers might even offer the same literary works in different (re) translations at the same time, a situation that is relatively typical 
for our digital age, which also increases the importance of the available (online and offline) reviews. Wardle investigates how the attention of potential customers tends to shift from professional reviews to online customer appraisals and star-ratings, apart from other "paratextual elements such as book covers". Her research reveals how readers' choices are not purely based on the (alleged) quality of the translation alone, but also on "availability, marketing strategies, price, prominence and distribution network of the publishing companies, star-ratings and levels of appreciation registered by fellow consumers".

The final paper in this volume, by Vitor Alevato do Amaral, problematizes the concept of 'retranslation' and pleads for the reconsideration of the existing definition of the phenomenon, by abandoning "the limitation to the same target language into which a given source text has already been translated". The author regrets "the lack of theoretical discussion" on this issue and instead builds on the ideas of Antoine Berman to suggest a new multilingual approach which should open up a multitude of new research opportunities. By considering earlier translations in other languages as possible links in the translation history of a particular literary work, and by including them into the corpus for retranslation research, a whole network of new interconnections is revealed, and the existing research can be refined. Hence, the closing article of the volume should be considered not as a ending, but as a potentially new beginning for research on retranslation.

Additionally to these contributions, this volume contains an interview and two book reviews. Retranslators should also have a voice in a special issue on retranslation. Therefore, Guillermo Sanz Gallego conducted an interview with the two authors of the third Spanish translation of James Joyce's Ulysses, Francisco García Tortosa and María Luisa Venegas Lagüéns. Among other details, the two translators provide their view as regards the reasons for retranslating Ulysses, their approach, their methodology, and their target reader. Also, the translators reveal how their translation had to face an embargo due to Joyce's grandson, who was the copyright 
holder at the time, and threatened with legal action. Finally the translation was published and it has managed to stand the test of time. In fact, according to Venegas, it ages quite well, like good wine. Her view is confirmed by Tortosa, who refers to good sales figures. The introduction to this interview highlights the quality of this translation as well: a recent research on translations and retranslations of Joyce's Ulysses conducted by Kris Peeters (University of Antwerp) and Guillermo Sanz Gallego (Ghent University/Vrije Universiteit Brussel, VUB) shows that both this Spanish retranslation and the third Dutch retranslation are at the same time more source oriented and target oriented. This research is under peer review for publication at the time of publication of this special issue.

The reader of this special issue will also find two book reviews. One of them, by Guillermo Sanz Gallego, is devoted to the publication of the Spanish translation of two comedies by Frances Burney. Carmen María Fernández Rodríguez is the author of the translations, and María Jesús Lorenzo-Modia is the author of the Introduction. The translation of Frances Burney's work plays an important role in the cultural transfer of literature written by female authors in the $18^{\text {th }}$ century. Additionally, the presence and visibility of such works is essential in order to provide a thorough overview of the production of those authors who challenged the androcentric canon established at the time. The other review, by Piet Van Poucke, discusses the $21^{\text {st }}$ volume of the series New Trends in Translation Studies, devoted to Literary Retranslation in Context and published by Peter Lang. In this collective work the editors, Susanne M. Cadera and Andrew Samuel Walsh, present nine articles (and an Introduction) on the historical, social and cultural contexts of retranslation. The articles in the volume share a series of common features, as they all elaborate on the research results of the RETRADES (Studies on Cultural and Textual Interaction: Retranslation) project. The research papers are gathered around the specific interaction between "Retranslation and Ideology", "Retranslation and Censorship", and "Retranslation and Reception". 


\section{References}

Alvstad, Cecilia, and Alexandra Assis Rosa. "Voice in retranslation. An overview and some trends." Target, vol. 27, no. 1, 2015, pp. 3-24.

Banoun, Bernard, and Irene Weber Henking (Eds.). Traduire - Retraduire. Lausanne: Centre de Traduction Littéraire, 2007.

Béghain, Véronique. Quand L'Europe retraduit “The Great Gatsby" : Le corps transfrontalier du texte. Pessac: Presses universitaires de Bordeaux, 2013.

Bensimon, Paul. "Présentation.” Palimpsestes, vol. 4, 1990, pp. ix-xiii.

Berk Albachten, Özlem, and Şehnaz Tahir Gürçağlar (Eds.). Perspectives on Retranslation: Ideology, Paratexts, Methods. New York/London: Routledge, 2018.

Berman, Antoine. "La retraduction comme espace de traduction." Palimpsestes, vol. 4, 1990, pp. 1-7.

Brownlie, Siobhan. "Narrative theory and retranslation theory." Across Languages and Cultures, vol. 7, no. 2, 2006, pp. 145-170.

Cadera, Susanne M., and Andrew Samuel Walsh (Eds.). Literary Retranslation In Context. Oxford [etc.]: Peter Lang, 2017.

Collombat, Isabelle. "Le XXIe siècle : l'âge de la retraduction." Translation Studies in the new Millennium, vol. 2, 2004, pp. 1-15.

Courtois, Jean-Patrice. De la retraduction : Le cas des romans. Bruxelles: Lettre volée, 2014.

Deane-Cox, Sharon. Retranslation : Translation, Literature and Reinterpretation. London [etc.]: Bloomsbury Academic, 2014. 
Létot-Douglas, Virginie, and Florence Cabaret (Eds.). La retraduction en littérature de jeunesse. Bruxelles [etc.]: Peter Lang, 2014.

Kahn, Robert, and Catriona Seth (Eds.). La retraduction. Mont-Saint-Aignan: Publications des universités de Rouen et du Havre, 2010.

Koskinen, Kaisa, and Outi Paloposki. "Retranslation." Handbook of Translation Studies, Volume 1, edited by Yves Gambier and Luc van Doorslaer, Amsterdam/ Philadelphia: John Benjamins, 2010, pp. 294-298.

Monti, Enrico, and Peter Schnyder (Eds.). Autour de la retraduction : Perspectives littéraires européennes. Paris : Orizons, 2011.

O'Driscoll, Kieran. Retranslation Through the Centuries: Jules Verne In English. Oxford [etc.]: Peter Lang, 2011.

Pokorn, Nike K. Post-socialist Translation Practices : Ideological Struggle In Children's Literature. Amsterdam: Benjamins, 2012.

Tahir Gürçağlar, Şehnaz. "Retranslation.” Routledge Encyclopedia of Translation Studies. Second edition, edited by Mona Baker and Gabriela Saldanha, London/ New York: Routledge, 2009, pp. 233-236.

Piet Van Poucke. E-mail: Piet.VanPoucke@ugent.be ORCID: https://orcid.org/0000-0003-1725-6558

Guillermo Sanz Gallego E-mail: Guillermo.SanzGallego@UGent.be ORCID: https://orcid.org/0000-0003-2945-4615 